\title{
Universities as Royal Courts: A Fable ${ }^{1}$
}

\author{
Paul De Frijters ${ }^{2}$
}

One of the stranger beasts to emerge from education reform in recent decades has been the Australian University. Though there are still about 38 of them left in the wild, they are nevertheless endangered. Indeed, their survival is threatened by self-harm - which can extend as far as their taking the axe to perfectly healthy faculties and schools within their domain. ${ }^{3}$

What are we to think about these social organisms? Do they operate like a business, where the threat of bankruptcy and competition keeps the hierarchy in check and determines their wages? Or are they ministries, answerable to politicians? The truth is, alas, that Australian universities resemble neither firms nor ministries. In fact, they operate more like the old royal courts of Europe, Asia and Africa.

Like its counterparts of old, the Australian university has a king. Although these kings have far more power than their North American and European kinsmen, they spend most of their time securing their power-base and the compliance of their liegemen, and so have little time to really understand what most of the underlings are doing. To save himself this trouble, he surrounds himself with a court of high-level administrators whose role it is to vie for access to the royal presence and whisper in his ear the things he wants to hear, always with a view to strengthening their own positions within the realm.

The king and his earls and counts receive petitioners from the outer reaches of the realm where production takes place. These petitioners usually come to beg for a share of the kingdom's resources: administrators seeking finance to subsidise their latest ventures; academics petitioning for positions; and students seeking help in their fights with other students and academics. The regal council has the power to pass judgement on these minor squabbles, granting or withholding favours in a manner that keeps everyone hopeful and in line without bankrupting the court.

The economy of the royal domains is quite intricate: on the one hand, the money stream on which the court floats comes from local student numbers determined

\footnotetext{
1 Editor's note: Agenda welcomes submissions expressing positions on the state of Australian universities.

2 University of Queensland; p.frijters@uq.edu.au

3 Recent examples include the axing of the Arts Faculty at QUT, whose underlying budget at the time was in the black, and where its many students were transferred to other faculties with otherwise low numbers; or the move of the school of Economics at the University of Sydney from the Business Faculty to the Arts Faculty. Both happened against the express wishes of the schools, faculties, and general academic opinion.
} 
by the broader imperial bureaucracies, within which each of the constituent educational mini-kingdoms sits. However, so parsimonious have the imperial bureaucracies become that the kingdom is increasingly dependent on another source of income - that produced by a rising tide of international students who come to learn English and perhaps procure a visa that will give them future access to the realm's riches. The fees to be paid for this privilege are high and to ensure the continued flow of these funds, ambassadors are sent to foreign lands to establish ties with other courts, to their mutual benefit.

Nevertheless, the Courts of Academe must also ensure that they remain on good terms with the domestic bureaucracies that are directly responsible for the money flows - the departments deciding on HECS places, accreditation, research funds, and special state interests such as Defence or Agriculture from which there is potential money to be had. This is an intricate and delicate game that entails singing a recurring refrain of being 'starved for cash' while, at the same time, having pretensions to be 'world beating'.

In addition to their principal sources of income, the courts need to keep an eye on the general levies imposed on all activities within the realm. Anyone making any money in the realm is taxed to give the king his due. Many of these moneygenerating activities, though, are hidden, so the king finds himself in a murky legal area having to grapple with the arcana of patent laws, intellectual property rights, definitions of 'consultancy' and other legally pliable distinctions between university and residential property. The king is forever having to deal with troublesome academics who hide their ' $\mathrm{IP}^{\prime}$ from him, property developers who want to build something in the realm (and with whom deals can be made), internal accountants who ensure that the individual territories (known as 'faculties') pay their dues, and lawyers brought in to protect him from outside forces.

A recurring characteristic of this royal court system is the self-serving behaviour of all its nobility. The various dukes, earls and barons forever endeavour to pay less to the king than is due from their individual fiefdoms, abusing the loopholes that the central tax-gatherers have left open. They also try to pinch business from each other by advertising their wares amongst commoners ('students') in a bid to lure them to their particular faculties.

Not surprisingly, perhaps, the central court bureaucracy is a similarly peculiar creature. It comprises men (and the occasional woman) of ambition, who build their own little empires using the argument that activities are best organised centrally because of the famed (though infrequently sighted) 'synergies' and 'network externalities' that can be brought to bear by doing so. They preside over burgeoning bureaucracies that vie with the other bureaucracies for roles and resources, the golden rule of their employment being to shore up their own 
interests while promoting the ambitions of their masters. ${ }^{4}$ The time-honoured and celebrated 'suck up, kick down' principle is innate in the culture of the royal courts.

Another noteworthy aspect of these royal courts is their penchant for luxury items and pageantry. This love of pageantry is evident even in the outer halls, where attractive secretaries ensure that all visitors have to wait before their arrival is announced with the fanfare that is due their rank. The royalty enjoys huge personal working and reception rooms with their expensive paintings; executive yachts; CEO retreats and other displays of wealth. These visible ornaments to their prestige are boosted by the celebrated academics they are able to attract to the realm and are another principal means by which kings try to out-do each other. The celebrity professors can be a bit noisy and selfcentred, but their employers have learned that this is the nature of this particular ornament and that there are enough of them in the world to ensure that the more irksome specimens can be replaced easily enough. ${ }^{5}$

Now and then, of course, the king must be seen by his subjects and allow for grievances (though none pertaining to his royal person) to be brought before him. To this end, he occasionally travels to the outer reaches of the realm, delivering lofty speeches and inviting selected academics to ask him anodyne questions of no significance, and ignoring the occasional outcry of disgruntled subjects. The pinnacle of such events is 'the strategic retreat', a once-a-year event in which the top 200 bureaucrats and academics are invited to come and pay their respects to the king in a series of private audiences wherein due deference can be shown and favours can be asked.

What is not commonly understood about these royal courts, particularly by those outside the palace gates, is that the royal court itself is a snake-pit where the barons eye and vie with each other for the top spots, particularly the throne itself. The king and his closest advisors are thus forever watching their backs for ambitious court members seeking to unseat them through adverse media coverage or accusations of wrongdoing. Paranoia is never too far beneath the highly polished surfaced: potentially, these confidantes and close advisors present the greatest threat to the throne and he must always keep an eye open for any sign of disloyalty, treachery or overweening ambition.

4 On the basis of telephone books and time-use surveys, I have calculated that around 70 per cent of the resources in the tertiary education sector went to intermediary activities, rather than teaching and research (Frijters 2011). The ratio of administrators to academics in the phonebook amongst Australian universities is around 2:1, higher than the numbers produced by universities themselves (which is 1.3:1).

5 The displays of conspicuous consumption and conspicuous leisure at these universities are perfectly in line with the arguments of Veblen (1899). The use of personal adornments amongst these royals, such as expensive suits or 'honorary' academic titles is discussed at http://economics.com.au/?p=9696 
Another imperative not commonly understood is the need of the king to keep everyone - knights, earls, and commoners alike — busy by focusing on projects and 'strategic visions'. There must be an infinite succession of visions and plans that involve as many of the potential lower-order troublemakers (academics and top bureaucrats) as possible. Assurance of learning programs, research excellence drives, teaching evaluations, equity programs and the like are all designed to engage the underlings in activities that reinforce loyalty. They give the royal bureaucracy a common goal and a common enemy as they measure and bully the truly independent potential troublemakers: the academics.

What is not widely understood, either, is that the potential troublemakers lower down - academics - are generally harmless creatures, quite oblivious to what is going on around them. For the most part, they keep their noses out of the big fights, concentrating instead on their own little battles with their peers, scrapping for scarce resources. They find pride and self-esteem in their lecturing and their latest research programs, forever congratulating themselves on their achievements and manoeuvrings. As long as they don't truly challenge royalty, they are tolerated. Occasionally, when some of the more politically savvy (or greedy) present a problem to the court, they can always be assimilated into the ranks of the royals.

What is commonly understood, though, is that royal courts grab as many resources as they can. The university senates, which are nominally sovereign, comprise people closely aligned to the court, and invariably include no more than one academic. ${ }^{6}$ The royal stipends (a system of huge salaries and bonuses) are similarly organised as an agreement between the constituent members of the royal court: the one thing they can invariably agree on is how deserving they are of the court's largesse. One upshot is that kings (and their accommodating bureaucratic underlings) are rewarded with immense salaries. ${ }^{7}$

The main danger that the royals face, apart from each other, is the outside media. Since the royal realms are not self-sufficient and exist by the grace of the imperial bureaucracies, it is in their best interests to ensure that the imperial bureaucracy is not alerted to any problems within the realm. Thus, the king and nobles are devoted to the maintenance of good relations towards the outside

6 The historical trajectory leading to this reality is nicely penned down by Milne (2001). Recent developments are discussed by Williams (2012). Own calculations reveal that in 2011 only 14 per cent of the members of university councils had a PhD.

7 Timothy Devinney calculated in May 2013 that the top leadership at Australian universities earn at least double what their counterparts at comparable universities in the US and the UK receive; probably triple if one includes bonuses and pensions. See http://clubtroppo.com.au/2013/05/15/timothy-devinney-on-overpaidvice-chancellors/ 
world, particularly the media. There is therefore an extreme aversion to bad press. $^{8}$ To ensure that nothing untoward reaches the wrong ears, the university's public image is very tightly controlled.

What is true of the empire's constituent kingdoms is also true of the empire. The ultimate aim of all is to protect themselves from their rivals while seeking to expand into the territories of others. To this end, there is a perennial stream of initiatives to prevent losses and initiate expansion. The battleground includes research assessment exercises, new laws on student loans, new rules on delineations between disciplines, and new pots of money for particular purposes ('Research Priorities'). This squares the circle and means that in any individual realm even the well-meaning realise they really do need a king to do their bidding in these territorial disputes.

\section{References}

Frijters, P. 2011, 'Presentation on Academonomics', Australian Conference of Economists, July 2011 . Available at: http://clubtroppo.com.au/2012/11/19/theuniversity-coalface-gets-28-cents-in-the-dollar/presentation-academonomicsace-july-2011/

Martin, R. E. and Hill, R. C. 2013, 'Measuring Baumol and Bowen Effects in Public Research Universities (30 January 2013). Available at SSRN: http:// ssrn.com/abstract=2153122 or http://dx.doi.org/10.2139/ssrn.2153122

Milne, F. 2001, 'The Australian Universities: a study in public policy failure', Queens University working paper, January 26th. Available at: http://qed. econ.queensu.ca/working_papers/papers/qed_wp_1080.pdf

Veblen, T. 1899, The theory of the leisure class, Macmillan.

Williams, Ruth F. G. 2012, 'The Academy in Decay', Agenda 19(2): 123-30.

8 Australian universities make it a sacking offence to bring the university 'into disrepute' (by their judgement); a fairly blatant form of censorship that prevents self-analysis. 